\title{
NOTE
}

\section{Timing of larval release in the mole crab Emerita talpoida}

\author{
Mark Amend ${ }^{1}$, Alan Shanks ${ }^{2, *}$ \\ 'Oregon Department of Fish and Wildlife, 2040 SE Marine Science Dr, Newport, Oregon 97365, USA \\ ${ }^{2}$ Oregon Inst. of Marine Biology, PO Box 5389, Charleston, Oregon 97420, USA
}

\begin{abstract}
The timing of larval release by the mole crab Emerita talpoida was followed for more than 2 mo at a beach near Duck, North Carolina. USA. The time series of the frequency of females carrying gray-stage eggs (i.e. fully developed eggs) was compared statistically to the time series of along- and cross-shore wind stress, salinity, water temperature, tidal range, and average significant wave height. The coastal oceanography was dominated by the wind. Winds from the northeast caused downwelling events and large waves in the surf zone while winds from the southwest caused upwelling and small surf. Drops in the frequency of females with gray-stage eggs (an indication of larval release) tended to occur a day after large wave events (cross-correlation, $r=-0.304, \operatorname{lag}=-1 d, p<0.05, n=53$ ). Large wave events cause rapid flushing of the water in the surf zone. Larvae released during large wave events would experience a short residence time in the surf zone that may decrease mortality due to benthic and surf zone predators.
\end{abstract}

KEY WORDS: Hatching - Spawning - Hatching cues - Mole crabs - Emerita talpoida - Zoea

Hatching rhythms are common in intertidal decapods (Forward 1987). Most hatching rhythms are endogenous and approximate environmental patterns such as lunar, tidal, and diel cycles (DeCoursey 1979, Christy 1982, Forward 1987, De Vries \& Forward 1991, Morgan \& Christy 1994, 1995). By affecting dispersal, the timing of spawning or larval release of marine invertebrates may affect the viability of the young (Giese \& Pearse 1974, Giese \& Kanatani 1987). The oceanographic conditions at the time of larval release coupled with the behavior of the larvae will determine the initial pattern of dispersal of the larvae. For example, adult female blue crabs migrate to the mouth of the estuary, where larval release occurs during ebbing tides (Provenzano et al.

\footnotetext{
- Addressee for correspondence.

E-mail: ashanks@oimb.uoregon.edu
}

1983). Newly hatched first stage zoea migrate to the surface, where the tidal currents carry them into the coastal waters (Provenzano et al. 1983). Because of these behaviors the development of the larvae occurs in the waters over the continental shelf.

A large portion of the research on decapod larval release has been carried out on intertidal estuarine and tropical crabs (Forward 1987, Morgan 1995). In a review of larval release rhythms, Forward (1987) lists 14 intertidal species that exhibit hatching rhythms. Only 3 of these inhabit 'exposed' shores (Christy 1986), i.e. areas where the intertidal zone is under the influence of a surf zone and the coastal ocean. The oceanography of exposed shores is significantly different to that within an estuary and, hence, one might expect to find different patterns of larval release on exposed shores than in estuaries. For example, larvae might be released during periods of wind driven upwelling or downwelling or during periods of large waves. The purpose of this study, a part of the Coastal Ocean Processes Pilot study (Butman 1994), was to examine the relationship between oceanographic conditions and larval release by Emerita talpoida, the mole crab.

Mole crabs Emerita talpoida live in the swash zone of exposed sandy beaches along the East Coast of North America. These abundant filter feeders migrate up and down the beach face with the tides. Reproduction in $E$. talpoida typically occurs from late winter through early fall with a maximum number of ovigerous females in the late summer (Diaz 1980). Following fertilization, the developing eggs are a bright orange color and are attached to the female's pleopods (Snodgrass 1952). As development progresses, the eyespots of the developing embryos become visible, the eggs take on a dirty gray appearance and soon hatch as zoea. There are no determinations of gestation time for E. talpoida, but in a related species, $E$, analoga, gestation time in the laboratory $\left(25^{\circ} \mathrm{C}\right.$ ) is $18 \mathrm{~d}$ (Fusaro 1977 ). 
Methods. In the late summer and early fall of 1994 , Emerita talpoida were collected from a beach on the Outer Banks of North Carolina (Fig. 1). The samples were collected from a $500 \mathrm{~m}$ stretch of beach located south of the research pier at the Army Corps of Engineers Field Research Facility (FRF) (Duck, North Carolina; $36^{\circ} 10^{\prime} 54.6^{\prime \prime} \mathrm{N}, 75^{\circ} 45^{\prime} 5.2^{\prime \prime}$ W). Mean annual beach width, from foredune edge to mean sea level, is $40 \mathrm{~m}$ and the mean annual foreshore slope is 0.108 (Birkemeier et al. 1981). Tides are semidiurnal, with a mean annual range of $1 \mathrm{~m}$. Wave direction is primarily from the south in the summer and from the north in the winter, with a mean annual wave height of $0.9 \mathrm{~m}$ (Birkemeier et al. 1981).

The egg condition of Emerita talpoida was determined by collecting sexually mature females (carapace length $>13.2 \mathrm{~mm}$ ) and scoring the status of their eggs. Daily

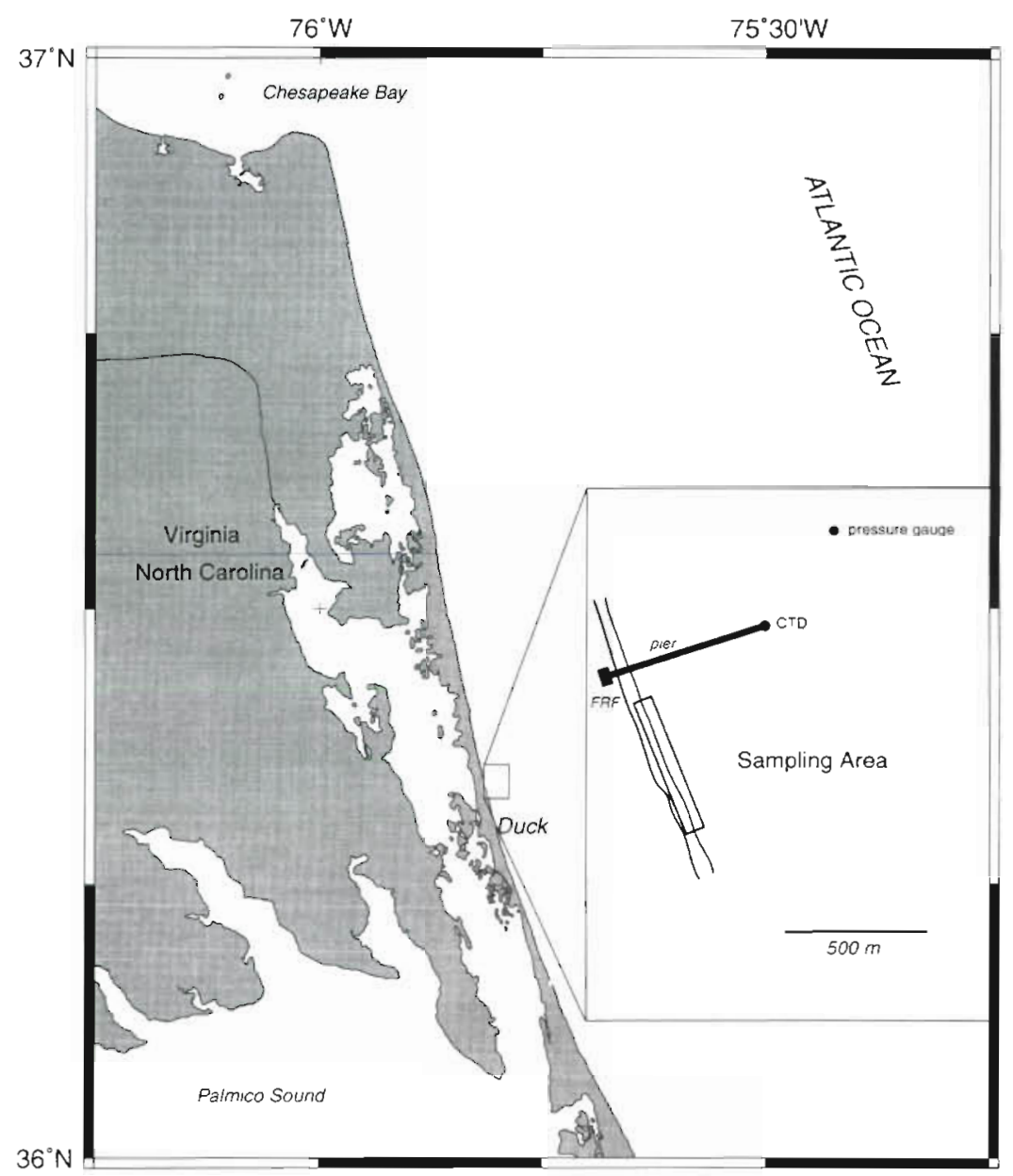

Fig. 1. Study site at Duck, North Carolina, USA. The Army Corps of Engineers Field Research Facility (FRF) was used as the center of operations. A CTD mounted on the end of the FRF pier measured salinity and water temperature. A pressure gauge located at $8 \mathrm{~m}$ depth $400 \mathrm{~m}$ northeast of the pier measured wave height. A $500 \mathrm{~m}$ section of the beach on the south side of the FRF pier was sampled daily for ovigerous Emerita talpoida sampling extended over 53 consecutive days, from 9 August to 29 September 1994, at which time eggbearing crabs were no longer present. Crabs were haphazardly collected by taking 3 to 51 sand samples from the lower part of the swash zone at about 16:00 h Eastern Standard Time each day. Crabs were sorted from the sand, and egg condition was examined by lifting the telson and noting the developmental stage. The eggs were scored for their stage of development following the scale developed by Dugan et al. (1990). The stages were: non-ovigerous (no eggs present), new (reddish orange eggs present), eyespot (reddish orange eggs with black eyespots), and gray (eggs gray in color, no eyespots obvious). The frequency of ovigerous females with gray-stage eggs was determined.

The time series of egg condition was compared to alongshore and cross-shore wind stress, significant wave height (average height of the largest third of the waves), tidal range, salinity, and water temperature. Physical variables were acquired from the FRF (Birkemeier et al. 1985) and investigators in the CoOP project (Alessi et al. 1996). Using wind direction and wind speed data provided by the FRF facility, wind stress was calculated with standard techniques (Pedlosky 1987). Wave height was measured with a pressure gauge located at $8 \mathrm{~m}$ depth (referenced to National Geodetic Vertical Datum, NGVD) approximately $400 \mathrm{~m}$ east-northeast of the pier (36 $11^{\circ} 14.06^{\prime \prime} N, 75^{\circ} 44^{\prime} 37.11^{\prime \prime} \mathrm{W}$ ). Tidal range was measured with a Baylor tide gauge mounted on the FRF pier. CoOP investigators provided salinity and water temperature data measured with a SeaBird SBE-15 SeaCat CTD mounted on the FRF pier at $4 \mathrm{~m}$ depth with respect to NGVD (Alessi et al. 1996). All physical variables were converted to $24 \mathrm{~h}$ daily averages to allow temporal comparisons with the time series of egg condition.

Prior to the time series analyses, the frequency of ovigerous females with gray-stage eggs was arcsine-transformed (Sokal \& Rohlf 1995). To aid in the identification of transformations to be used in modeling, autocorrelations and partial autocorrelations of each variable were used to test for trends and periodicity in the time series (Box \& Jenkins 1976, Chatfield 1989, Dun- 


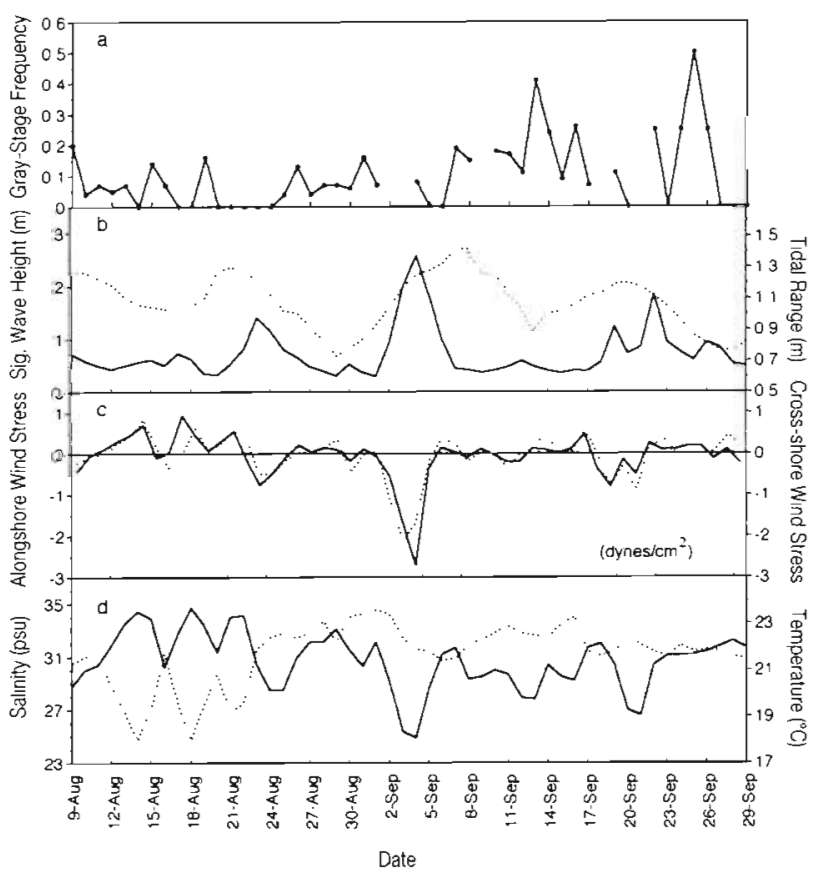

Fig. 2. Frequency of female Emerita talpoida carrying graystage eggs (a) plotted with physical oceanographic data. (b) Significant wave height and tidal range. (c) Alongshore and cross-shore wind stress. Wind stress is positive when the winds were from the south and west and negative when from the north and east. (d) Salinity and water temperature. In (b-d), solid and dotted lines represent data from the left- and right-hand axes, respectively

stan 1993). Where appropriate, time series were transformed using Statistica prior to running cross-correlations. The time series of salinity, temperature, and arcsine-transformed frequency of females with graystage eggs were detrended and the autocorrelation was removed from the significant wave height data. Significance of all correlations $(p<0.05)$ was determined using white noise standard errors (Box \& Jenkins 1976). Cross-correlations were limited to $10 \%$ of the length of the entire time series (Otnes \& Enochson 1978). Negative lags correspond to days prior to the occurrence of the dependent series (e.g. $-1 \mathrm{~d}$ equals 1 day before hatching occurred). Positive lags were disregarded due to the unlikely possibility that the dependent series could occur prior to the independent series (e.g. animals are not likely to 'predict' the crossshore wind stress).

Results. Physical data: During the study, the winds tended to blow from either the northeast or the southwest. The strongest winds were from the northeast, the so-called 'northeasters' (Fig. 2). Maximum alongshore and cross-shore wind stresses were -2.717 and -2.158 dynes $\mathrm{cm}^{-2}$, respectively, and occurred during a northeaster. Changes in the wind direction were coincident with changes in the other physical variables.
Significant cross-correlations were found between salinity, water temperature, significant wave height, and along- and cross-shore wind stress (Table 1). Alongshore wind stress was significantly positively correlated with both cross-shore wind stress and salinity at 0 and $-1 \mathrm{~d}$ lag and was significantly negatively correlated with both water temperature (0 d lag) and significant wave height ( 0 and $-1 \mathrm{~d}$ lag). Cross-shore wind stress was significantly positively correlated with salinity at 0 and $-1 \mathrm{~d}$ lag and significantly negatively correlated with temperature ( 0 and $-1 \mathrm{~d}$ lag) and significant wave height ( $0 \mathrm{~d}$ lag). In summary, the correlations indicate that during winds from the northeast lower salinity, warmer water was found against the coast and there was an increase in wave height. Winds from the southwest were associated with higher salinity, colder water and a decrease in wave height.

Biological data: The number of crabs sampled (ovigerous and non-ovigerous) per day ranged from 6 to 179 (Mean $=94, \mathrm{SE}=5.89$, Fig. 3). Smaller sample sizes early in the study were a result of unforeseen logistical difficulties. Due to dangerous conditions in the swash zone $(2,3,18,21$ September) and logistical problems ( 9 September) samples were missed on 5 days (Fig. 3). In the subsequent time series analysis, missing data were not replaced with estimates from previous days' data. The extremely low numbers of ovigerous crabs late in the study period indicate that the reproductive season ended about 29 September. The percentage of ovigerous crabs with gray-stage eggs ranged

Table 1. Results of cross-correlations between wind stress and the physical variables. Prior to running the cross-correlations the salinity and water temperature data were detrended and the autocorrelation was removed from the significant wave height data. Variables are listed with their corresponding cross-correlation coefficients (standard error in parentheses) and lags in days. Only significant correlations are shown $(p<0.05, n=53)$

\begin{tabular}{|lcr|}
\hline & $r$ & Days lag \\
\hline Alongshore wind stress & & \\
Cross-shore wind stress & $0.884(0.139)$ & 0 \\
& $0.490(0.140)$ & -1 \\
Salinity & $0.659(0.139)$ & 0 \\
& $0.665(0.140)$ & -1 \\
Temperature & $0.284(0.141)$ & -2 \\
& $-0.302(0.139)$ & 0 \\
Significant wave height & $-0.335(0.140)$ & -1 \\
Cross-shore wind stress & $-0.617(0.140)$ & 0 \\
Salinity & & \\
& $0.755(0.139)$ & 0 \\
Temperature & $0.674(0.140)$ & -1 \\
Significant wave height & $-0.435(0.139)$ & 0 \\
& $-0.665(0.140)$ & 0 \\
& $-0.424(0.141)$ & -1 \\
\hline
\end{tabular}




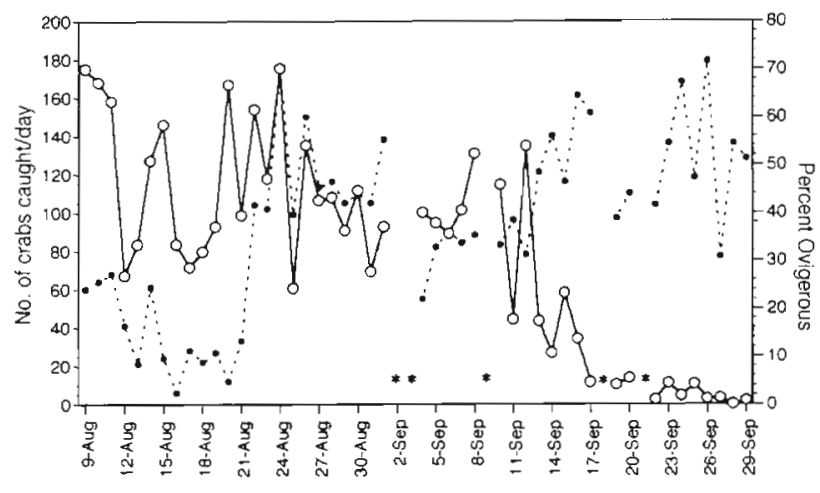

Date

Fig. 3. Daily sample sizes of female Emerita talpoida (--- - and percent ovigerous females $(-0-)$. Asterisks indicate missing samples $(2,3,9,18$ and 21 September $)$

from 0 to $50 \%$ (Fig. 2). Sharp drops in this percentage were attributed to larval release, the hatching of zoea from gray-stage eggs.

The absence of significant autocorrelations around 7 and $14 \mathrm{~d}$ in the frequency of females with gray-stage eggs indicates that there was not an inherent fortnightly hatching rhythm in this Emerita talpoida population. The only significant cross-correlation was found between significant wave height and the percentage of females with gray-stage eggs (Table 2). The percentage of gray-stage females was significantly lower $1 \mathrm{~d}$ after large wave events (Table 2), suggesting that $E$. talpoida released larvae during periods of large waves.

Discussion. Over the duration of the study, the coastal oceanography was dominated by the winds. During northeasters, strong winds pushed warmer, lower salinity surface waters onshore, causing downwelling events and large waves in the surf zone. Dur-

Table 2. Results of cross-correlations between the frequency of females with gray-stage eggs and physical variables. Prior to running the cross-correlations, the frequency of females with gray-stage eggs time series was arcsine-transformed and detrended, the salinity and water temperature data were detrended, and the autocorrelation was removed from the significant wave height data. Variables are listed with their corresponding cross-correlation coefficients (standard error. in parentheses) and lags in days. Only significant correlations are shown $(p<0.05, n=53)$

\begin{tabular}{|lcc|}
\hline & r & Days lag \\
\hline Alongshore wind stress & - & - \\
Cross-shore wind stress & - & - \\
Salinity & - & - \\
Temperature & - & - \\
Significant wave height & -0.304 & -1 \\
& $(0.141)$ & \\
\hline
\end{tabular}

ing southwesters, steady light winds blew offshore, causing the surface waters to be pushed offshore. Colder, higher salinity bottom waters upwelled at the coast, replacing the exported surface waters. During southwester winds, waves in the surf zone were small.

The statistical analysis suggests that the percentage of female mole crabs carrying gray-stage eggs varied with the physical oceanography. Large waves, driven by northeasters and lasting several days, were correlated with a decrease $1 \mathrm{~d}$ later in the number of females with gray-stage eggs. Thus, larval release in Emerita talpoida appears to occur during storm events when waves in the surf zone are large.

With increasing wave height, rip currents intensify and the residence time of water in the surf zone decreases (Inman et al. 1971, Talbot \& Bate 1987). Talbot \& Bate (1987) found that the half-residence time (i.e. the time needed for half the surf-zone water to be exchanged with the nearshore) varied from days during periods of small waves to tens of minutes during large wave events. During periods of large waves, the residence time of water in the surf zone is short. As a consequence of this short residence time, larvae released into the surf zone during periods of large waves should be rapidly exported out of the surf zone.

Talbot \& Bate (1987) also found that even during periods of large waves positively buoyant particles are retained in the surf zone but neutrally buoyant particles are transported out of the surf zone. The larval behavior of Emerita talpoida has not been investigated. Burton (1979), however, investigated the behavior of newly released larvae of the closely related West Coast mole crab E. analoga. He found that immediately after hatching first stage zoea were photopositive, but in $<1 \mathrm{~h}$ most were photonegative. At atmospheric pressure, the larvae remained on the bottom of a vertical tube, but a pressure increase of $10 \mathrm{~cm} \mathrm{Hg}$ (equivalent to a $1.3 \mathrm{~m}$ increase in depth in seawater) caused the larvae to swim up off the bottom of the tube. The behavior of newly released $E$. analoga zoea should direct them away from the ocean's surface and maintain them at depths of around $1 \mathrm{~m}$. E. analoga zoea apparently act like neutrally buoyant particles and, hence, should be transported out of the surf zone. If recently hatched E. talpoida zoea behave similarly, then they should be flushed rapidly from the surf zone as well.

Predation on larvae is often cited as a possible selective pressure leading to hatching rhythms in intertidal decapods (Morgan \& Christy 1995, 1997). The survival of recently hatched larvae may be higher if they are transported away from the adult habitat, where predation is intense, and into the waters of the innercontinental shelf, where planktonic predators are less abundant (Christy 1982). Larval release during rough 
seas should minimize the time early larval stages spend in the surf zone and may thereby decrease the probability of their contact with predators in the surf zone.

Previously described hatching rhythms, whether lunar or tidal, are thought to act at the embryonic and maternal level (DeVries \& Forward 1991, Morgan \& Christy 1995). Embryonic hatching cues are believed to be endogenous and controlled entirely by the embryo, while maternal cues are thought to be exogenously controlled by physiological changes in the female caused by environmental cues (Morgan 1995). Therefore, a wave-driven hatching cue probably acts on the maternal level.

This is the first reported example of hatching in decapods during high wave activity. Storm-induced spawning, however, has been observed in a number of other taxa. In particular, spawning during large waves has been observed in a variety of archaeogastropods (e.g. limpets, abalone, and turban snails) (Orton \& Southward 1961, Grange 1976, Ohgaki 1981, Creese \& Ballantine 1983, Sasaki \& Sheperd 1995, Shanks 1997). Grange (1976) was able to induce spawning in the laboratory in a variety of gastropods by vigorous agitation of the water. This technique has also been used to induce spawning in bivalves as well (Strathmann 1987). In the field, larvae from these same gastropod species were found in the plankton only when the onshore wind speed was greater than 10 knots and the seas were rough. Frank \& Leggett (1981) found that emergence of larvae of the capelin Mallotus villosus was a result of beach disturbance by onshore windinduced wave action. Along exposed coastlines a diversity of intertidal organisms spawn or hatch during large wave events.

Acknowledgements. K. Johnson, T. Rippetoe, M. Hearn, the Army Corps of Engineers Field Research Facility, and, especially, R. Sweet provided field assistance. Drs S. Lentz, J. Austin, S. Elgar, R. Guza and the Army Corps of Engineers Field Research Facility provided physical oceanographic data. Drs S. Rumrill and R. Emlet provided valuable advice during the writing of this manuscript. The National Science Foundation, Coastal Ocean Processes Grants OCE-9123514 and OCE-9633071 supported this research

\section{LITERATURE CITED}

Alessi CA, Lentz SJ, Austin J (1996) Coastal ocean processes inner-shelf study: coastal and moored physical oceanographic measurements. Woods Hole Oceanogr Inst Tech Rep WHOI-96-06:142

Birkemeier WA, DeWall AE, Gorbics CS, Miller HC (1981) A user's guide to CERC's field research facility. CERC MR 81-7, U.S. Army Corps of Engineers, Waterways Experimental Station, Vicksburg, MS

Box GEP, Jenkins GM (1976) Time series analysis, forecasting and control. Holden-Day, San Francisco
Burton RS (1979) Depth regulatory behavior of the first stage zoea larvae of the sand crab. Emerita analoga Stimpson (Decapoda: Hippidae). J Exp Mar Biol Ecol 37:255-270

Butman CA (1994) CoOP: Coastal Ocean Processes Study: interdisciplinary approach, new technology to determine coupled biological, physical, geological processes affecting larval transport on the inner shelf. Sea Tech 1:44-49

Chatfield C (1989) The analysis of time series. Chapman and Hall, London

Christy JH (1982) Adaptive significance of semilunar cycles of larval release in fiddler crabs (genus $U_{c a}$ ): test of an hypothesis. Biol Bull 163:251-263

Christy JH (1986) Timing of larval release by intertidal crabs on an exposed shore. Bull Mar Sci 39:176-191

Creese RG, Ballantine WJ (1983) An assessment of breeding in the intertidal limpet, Cellan radians (Gmeline). J Exp Mar Biol Ecol 67:43-59

DeCoursey PJ (1979) Egg-hatching rhythms in three species of fiddler crabs. In: Naylor E, Hartnoll RG (eds) Cyclic phenomena in marine plants and animals. Pergamon Press, New York, p 399-406

De Vries MC, Forward RB (1991) Control of egg-hatching time in crabs from different tidal heights. J Crustac Biol 11:29-39

Diaz H (1980) The mole crab Emerita talpoida (Say): a case of changing life history patterns. Ecol Monogr 50:437-456

Dugan JE, Hubbard DM, Davis GE (1990) Sand beach and coastal lagoon monitoring handbook. National Park Service, Ventura

Dunstan FDJ (1993) Time series analysis. In: Fry JC (ed) Biological data analysis: a practical approach. Oxford University Press, New York, p 243-310

Forward RB (1987) Larval release in decapod crustaceans: an overview. Bull Mar Sci 41:165-176

Frank KT, Leggett WC (1981) Wind regulation of emergence times and early larval survival in capelin (Mallotus villosus). Can J Fish Aquat Sci 38:215-223

Fusaro C (1977) Population structure, growth rate, and egg production of the sand crab Emerita analoga (Hippidae): a comparitive analysis. PhD dissertation, University of California, Santa Barbara

Giese AC, Kanatani H (1987) Maturation and spawning. In: Giese AC, Pearse JS, Pearse VB (eds) Reproduction of marine invertebrates IX. General aspects: seeking unity in diversity. The Boxwood Press, Pacific Grove, CA, p $252-313$

Giese AC, Pearse JS (1974) Introduction: general principles. In: Giese AC, Pearse JS (eds) Reproduction of marine invertebrates, Vol 1. Academic Press, New York, p 1-49

Grange KR (1976) Rough water as a spawning stimulus in some trochid and turbinid gastropods. NZ J Mar Freshw Res 10:203-216

Inman DL, Tait RJ, Nordstrom CE (1971) Mixing in the surf zone. J Geophys Res 76:3493-3514

Morgan SG (1995) The timing of larval release. In: McEdward LR (ed) Ecology of marine invertebrate larvae, 1st edn. CRC Press, Boca Raton, p 157-191

Morgan SG, Christy JH (1994) Plasticity, constraint, and optimality in reproductive timing. Ecology 75:2185 - 2203

Morgan SG, Christy JH (1995) Adaptive significance of the timing of larval release by crabs. Am Nat 145:457-479

Morgan SG, Christy JH (1997) Planktivorous fishes as selective agents for reproductive synchrony. J Exp Mar Biol Ecol 209:89-101

Ohgaki S (1981) Spawning activity in Nodilittorina exigua and Peasiella roepstorffiana (Littorinidae, Gastropoda). Publ Seto Mar Biol Lab 26:437-446 
Orton $\mathrm{JH}_{1}$ Southward AJ (1961) Studies on the biology of limpets IV. The breeding of Patella depressa Pennant on the north Cornish coast. J Mar Biol Assoc UK 41:653-662

Otnes RF, Enochson L (1978\} Time series analysis: basic techniques. Wiley and Sons, New York

Pedlosky J (1987) Geophysical fluid dynamics. SpringerVerlag, New York

Provenzano AJ, McConaugha JR, Philips KB, Johnson DF. Clark J (1983) Vertical distribution of first stage larvae of the blue crab, Callinectes sapidus, at the mouth of the Chesapeake Bay. Estuar Coast Shelf Sci 16:489-499

Sasaki R, Sheperd SA (1995) Larval dispersal and recruitment of Haliotis discus hannai and Tegula spp. on Miyagi Coasts, Japan. Mar Freshw Res 46:519-529

Editorial responsibility: Otto Kinne (Editor),

Oldendorf/Luhe, Germany
Shanks AL (1997) Apparent oceanographic triggers to the spawning of the limpet Lottia digitalis. J Exp Mar Biol Ecol $222: 31-42$

Snodgrass RE (1952) The sand crab Emerita talpoida (Say) and some of its relatives. Smithson Misc Coll 117:1-34

Sokal RR, Rohlf FJ (1995) Biometry. WH Freeman and Company, San Francisco

Strathmann MF (1987) Reproduction and development of marine invertebrates of the Northern Pacific Coast. University of Washington Press, Seattle

Talbot MMB, Bate GC (1987) Rip current characteristics and their role in the exchange of water and surf diatoms between the surf zone and nearshore. Estuar Coast Shelf Sci $25: 707-720$

Submitted: October 15, 1998; Accepted: March 16, 1999 Proofs received from author(s): June 10, 1999 